\title{
Indicators of Chemical Life of the Biosphere
}

\author{
Hakima Yusupovna Salomova ${ }^{1} \&$ Kurbanov Nodirjon Mirzohidovich ${ }^{2}$ \\ ${ }^{I}$ Professor of Bukhara State University, Bukhara City, Uzbekistan. \\ ${ }^{2}$ Student of the $38^{\text {th }}$ Secondary Educational School of Bukhara City, Uzbekistan. \\ DOI: http://doi.org/10.46382/MJBAS.2021.5306
}

Copyright: () 2021 Hakima Y. S. \& Kurbanov N. M. This is an open access article distributed under the terms of the Creative Commons Attribution License, which permits unrestricted use, distribution, and reproduction in any medium, provided the original author and source are credited.

\section{ABSTRACT}

This article is devoted to the scientific analysis of the responsibility means that mankind partakes three dangers: the risk of war, ecological and spiritual poverty.

Keywords: Biosphere, Equilibrium, Atmosphere, Oxygen, Innovations, Water, Human beings, Ozone layer.

\section{Introduction}

The 21 st century has placed a great responsibility on humanity. One such responsibility is the problem of conserving the vital functions of the biosphere. Like any other species, man can live under certain conditions of the biosphere - a certain temperature, a certain pressure, against the background of natural radiation, certain chemical parameters - between parameters. It is in this case that the ecological balance in the biosphere is not disturbed.

Oxygen is always in dynamic equilibrium in the atmosphere. Due to the activities of the plant world, 1,011 tons of oxygen is released into the atmosphere every year. One hectare of pine forest releases 30 tons of oxygen a year. With 30 tons of oxygen, 19 people will be able to breathe for a year.

\section{Discussions}

The amount of oxygen consumed in the combustion of 100 liters of gasoline in car activity increases the biological need of a person to breathe throughout the year.

- Indeed, due to anthropogenic activity at a time when modern science and technology are advancing:

- Every year, 10 million people enter the world's oceans, tons of oil products;

- 1 billion tons of aerosols and bodies (due to industry and vehicles) into the air per year;

○ 500 billion tons of industrial and domestic waste per year in inland water basins;

- 30 billion tons of carbon dioxide $\left.\left(\mathrm{CO}_{2}\right)\right)$ is shipped;

Every year, $4,000 \mathrm{~km}^{3}$ of rocks are removed from the Earth's crust, which impairs the hydrogeological conditions of the earth.

These negative effects on the biosphere are reflected in the economies of countries.

Currently, 430,000 tons of lead is deposited in the ocean each year. The amount of industrial lead received in a year due to natural winds before it hit the ocean was only 11,000 tons. 
It is known to science that lead pollution of the ocean has been going on since 1940, when tetraethyl lead was used as an antidetonator for automotive gasoline.

$\mathrm{Pb}\left(\mathrm{C}_{2} \mathrm{H}_{5}\right)_{4}$ - despite the fact that tetraethyl lead is toxic to the engine.

It is a common antidetonator for fuel. North of the globe 350,000 tons of lead car into the atmosphere every year in the hemisphere emitted as gas, of which 250 thousand tons are released into the atmosphere as sediment leads to seawater. Machinery industry pollution caused by pollution in the biosphere a significant percentage.

In fact, the car industry is the youngest. Although industrial, it is a loss to nature, to environmental pollution much larger.

The natural background of carbon dioxide is 9 billion tons per year.

Tons, this figure are due to anthropogenic activity 25-30 billion tons.

This causes a "steamy crust" to form in the biosphere.

So, the transition to an environmentally friendly industry is a requirement of the times. According to the United Nations, $97 \%$ of the planet's water is saline, making it unsuitable for both irrigation and drinking. 3\% of the water is pure drinking water, two-thirds of which is available in the form of iceberg and mountain glacier water. Only $1 \%$ of the earth's water supply is water for human consumption.

Although the volume and amount of water as the main ecological component has not changed over the next five thousand years, during this time the world's population has increased several hundred times, technological innovations have been put into practice.

Today, drinking water remains the most unique and valuable natural resource. Today, 2 billion people suffer from a shortage of clean drinking water and every year 10 million people die from drinking contaminated and contaminated water.

The United Nations Environment Program (UNEP) recently warned that, by 2050, 30\% of the world's population will face the problem of drinking water shortages. This process has actually accelerated. The world's population is facing water shortages and water quality problems.

Today, $80 \%$ of diseases in developing countries are rooted in water pollution. According to the World Bank administration, the risk of drinking water shortages is currently increasing in 80 countries around the world. According to the UN, 1,700 liters of water per capita per year indicates a shortage of water, while 1,000 liters per capita per year indicates an environmental water crisis.

Experts predict that by 2025 , the water crisis will spread to 17 more countries, and India will not be left out of this recession. It is difficult to imagine the consequences if this threat threatens China as well.

A quarter of a century later, the water threat is estimated at $\$ 8$ billion, can be a threat, so it is necessary to start practical work on water conservation now. 


\begin{tabular}{|c|c|}
\hline \multicolumn{2}{|c|}{ Indicators of chemical life of the biosphere } \\
\hline $\begin{array}{l}\text { Natural-ecological nature of eco } \\
\text { components in the biosphere } \\
\text { standards }\end{array}$ & $\begin{array}{c}\text { Post-anthropogenic activity } \\
\text { indicators }\end{array}$ \\
\hline $\begin{array}{l}\text { Atmospheric composition } \mathrm{S}^{`} 21 \% \\
\text { oxygen }\left(\mathrm{O}_{2}\right) \text { forms. }\end{array}$ & $\begin{array}{l}\text { Every year, the reduction of oxygen due to deforestation is } \\
10-12 \text { billion tons. } 50 \text { hectares of forest are being cut down } \\
\text { in one minute. Decreased oxygen concentration in the air as } \\
\text { a result of its natural-ecological norm, ie from } 21 \% \text { to } 17 \% \text {, } \\
\text { leads to lethargy, loss of taste, fatigue, } 12 \% \text { decrease in } \\
\text { oxygen concentration is life-threatening, loss of } \\
\text { consciousness at less than } 11 \%, \text { loss of consciousness, } 6 \% \\
\text { in rare cases, cessation of breathing is observed. }\end{array}$ \\
\hline $\begin{array}{l}\left(\mathrm{CO}_{2}\right) \text {-carbon dioxide amounted to } 9 \\
\text { billion tons, showing an annual natural } \\
\text { output. }\end{array}$ & $\begin{array}{l}\text { Due to anthropogenic activity, } 25-30 \text { bln./Tons released into } \\
\text { the atmosphere. Due to the increase in carbon dioxide } \\
\text { created by its own architecture, by } 2050 \text { the appearance of } \\
\text { the planet will increase by } 1.5-40 \text {, the melting of glaciers } \\
\text { and } 1.5-2.5 \text { meters above sea level. (Intensification of } \\
\text { "Buyli q life") }\end{array}$ \\
\hline $\begin{array}{l}\left(\mathrm{SO}_{2}\right) \text { The natural content of sulfur } \\
\text { dioxide in the atmosphere is } 0.28-2.8 \\
\text { milligrams per cubic meter. }\end{array}$ & $\begin{array}{l}\text { Globally, the total amount of sulfur dioxide emitted into the } \\
\text { atmosphere per year is } 190 \text { million/t. Of this, } 120 \text { million } \\
\text { tons of sulfur oxides are released into the atmosphere } \\
\text { annually from industrial enterprises alone. }\end{array}$ \\
\hline $\begin{array}{l}\text { Nitrogen oxides } 30 \mathrm{mln} / \mathrm{t} \text {. } \\
\text { The natural rate of nitrogen oxides is } \\
\text { the criterion for the rate of ozone. Their } \\
\text { natural norms are as follows: } \\
\mathrm{N}_{2} \mathrm{O} \text {-nitric oxide }-2 \mathrm{mg} / \mathrm{m}^{3} \text {; } \\
\mathrm{NO} \text {-nitrogen dioxide }-0,02 \mathrm{mg} / \mathrm{m}^{3} \text {; } \\
\mathrm{NO}_{2} \text {-nitric } 4 \text { oxide }-0,02 \mathrm{mg} / \mathrm{m}^{3}\end{array}$ & $\begin{array}{l}65 \text { million / } t \text { due to anthropogenic activity. released into the } \\
\text { atmosphere. Besides, what is it called that a nitric oxide } \\
\text { "lives" in the atmosphere for } 200 \text { years? }\end{array}$ \\
\hline $\begin{array}{l}\text { The natural amount of chlorine in the } \\
\text { atmosphere is } 10 \text { to } 100,000 \text { tons per } \\
\text { year just enough. }\end{array}$ & $\begin{array}{l}\text { In a year due to anthropogenic factor } 850,000 \text { tons of } \\
\text { chlorine is released into the atmosphere. }\end{array}$ \\
\hline
\end{tabular}


The natural-ecological norm of lead: in the pre-industrial period, only 11,000 tons of lead fell into the ocean in a year due to natural winds.

Ozone is present in the air at an altitude of $10 \mathrm{~km}$ to $50 \mathrm{~km}$, the maximum amount of which is between $18-26 \mathrm{~km}$. The stratosphere contains a total of 3.3 trillion tons of ozone. If we accumulate this amount of ozone at normal pressure (760 mm / mercury column) and at a temperature of 200 degrees, then the thickness of this layer is a total of $2.5-3 \mathrm{~mm}$. This thickness is measured in quantities equal to one hundredth of a millimeter and is called the Dobson unit, i.e. 1 D.b. Is equal to $0.001 \mathrm{~cm}$. The ozone layer reaches its maximum value in the spring - 446 D.b. In the atmosphere, its normal amount (ie natural-ecological norm) is 300 Dobson units (D.b.). Although ozone in the stratosphere is constantly renewed, its amount is in a changing equilibrium. As you know, it's good that everything is in order.

The natural concentration of ozone in the air is $15-20 \mathrm{mcg} / \mathrm{m} 3$, which is the most optimal. The allowable amount is $100 \mathrm{mcg} / \mathrm{m}^{3}$.
Currently, 430,000 tons of lead are deposited in the ocean each year. It is known to science that lead pollution of the ocean began in 1940, when tetraethyl lead was used as an antidetonator for gasoline.

Although $\mathrm{Pb}(\mathrm{C} 2 \mathrm{H} 5)$ 4-tetraethyl lead is toxic, it is a common antidetonator for motor fuels. In the Northern Hemisphere, 350,000 tons of lead are emitted into the atmosphere each year as automobile gas, of which 250,000 tons are released into the sea as atmospheric sediments.

In 1985, the first ozone depletion in the skies of Antarctica was discovered, which became known as the "ozone hole." The literature on some environmental issues states that the amount of ozone in the stratosphere has decreased by $7.5 \%$ since 1976. In 1987, 40 million $\mathrm{km}^{2}$ over Antarctica. the ozone layer in the area was reduced to 200 D.b., which is practically equivalent to 600 southern circles.

Observations have shown that the concentration of chlorine oxides in such zones is high, which means that in places where the concentration of chlorine oxides is high, the natural rate of ozone decreases.

Due to the human activities, methyl chloride, tetrachloromethane, chlorofluoromethane, in short, compounds containing halogen atoms, called "freons", are accumulating in the atmosphere. They are the main sources of ozone depletion. Freons are long-lived "living" compounds that are stored in the atmosphere for 105-205 years. In 1974, 850,000 tons of chlorofluorocarbons, namely $\mathrm{F}-11$, ie trichlorofluoromethane $\left(\mathbf{C C l}_{3} \mathbf{F}\right)$ and $\mathrm{F}-12$, ie dichlorodeformer methane $\left(\mathbf{C C l}_{2} \mathbf{F}_{2}\right)$, were produced, and in 1976, 8.1 million tons of freons. When volcanoes erupt, between 10 and 100,000 tons of chlorine compounds are released into the stratosphere each year.

This means that the amount of freons released into the atmosphere due to natural and anthropogenic factors varies 


\begin{tabular}{|c|c|c|}
\hline & & 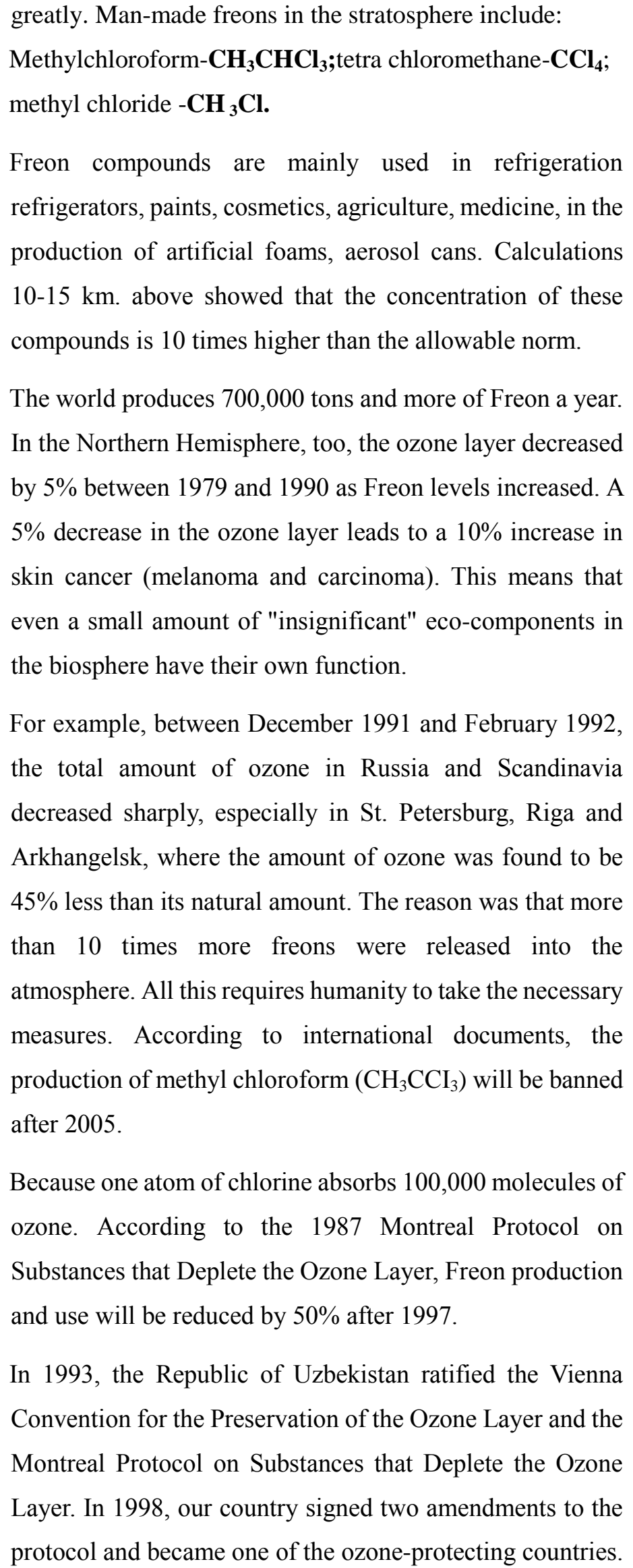 \\
\hline
\end{tabular}


Nature itself does not send oil and oil products to the oceans and seas.
According to the United Nations, 6-7 million tons of oil is spilled into the oceans a year. The results of the experiment show that one square mile per hour evaporates 97 tons of water in the absence of oil shells in the area, while if the oil covers the surface of the water, this figure is 45 tons. A decrease in the evaporation process reduces the possibility of saturation of the air mass with water vapor at ocean level.

\section{Results}

The above indicators are not all yet, except for one that is unique to all - the natural radioactivity on our planet Earth - which is also one of the indicators of the chemical life of a single biosphere. This, too, should never deviate from its natural norm. The negative consequences of this abnormality of natural radioactivity were reflected in the Chernobyl events.

\section{Conclusions}

1. Biosphere - Planet Earth - 7.7 billion. It is unique to humans.

2. Preserving the vital signs of the biosphere is a necessary and true human duty of every human being on the planet to Being.

\section{Air pollutant}

4. methylchloroform $\left(\mathrm{CH}_{3} \mathrm{CCI}_{3}\right)$ methyl chloroform $-\mathrm{CH}_{3} \mathrm{CHCl}_{3}$; tetrachloromethane $-\mathrm{CCl}_{4}$; methyl chloride- $\mathrm{CH}_{3} \mathrm{Cl}$; methyl bromide $-\mathrm{CH}_{3} \mathrm{Br}$;

F-11i.e. trichlorofluoromethane $\left(\mathrm{CCl}_{3} \mathrm{~F}\right)$;

F-12that is, dichlorode methane $\left(\mathrm{CCl}_{2} \mathrm{~F}_{2}\right)$

while banning all chemical production is much needed. The production of all components that deplete the ozone layer should be strictly limited.

5. It is necessary to increase the amount of oxygen in the atmosphere by not cutting down trees, increasing the planting of trees and shrubs in the territory of Uzbekistan in forests, hills, hills and deserts, suitable for their climate and soil.

6. Do not burn the leaves. After all, the chemical compounds released as a result of burning the leaves can cause people to get cancer. 
Declarations

\section{Source of Funding}

This research did not receive any grant from funding agencies in the public, commercial, or not-for-profit sectors.

Competing Interests Statement

The authors declare no competing financial, professional and personal interests.

\section{Consent for publication}

Authors declare that they consented for the publication of this research work.

\section{References}

1. Engineering ecology and environmental management. M. Logos. 2003. P.287.

2. VI Vernadsky and the present. M., "Science". 1986, p. 156.

3. Yu.A. Israel., F. Ya. Ravensky. Protect the biosphere. ., Pedagogy. 1987, p. 29.

4. YA Israel and D. King. Atmospheric azone - sensation and reality. L., Gidrometeoizdat. 1991.

5. Salomova H.Yu. Fundamentals of social ecology. T .: Science and Technology Publishing House. 2004.

6. Salomova H.Yu. Fundamentals of social ecology. T .: "Science and Technology" 2nd edition. 2008.

7. Salomova H.Yu. The philosophical essence and practical significance of the norm. Buxoro. "Durdona" .2019.

8. Salomova H.Yu. Ecology and economics. Buxoro. Bukhara Publishing House. 2008.

9. Philosophical problems of global ecology. M .: Nauka.1983.S.239.

10. Arguments and facts. 1992 February. No. S.8. 